\title{
PERANCANGAN GAME SEBAGAI MEDAI PEMBELAJARAN BERKEBUN HIDROPONIK
}

\author{
Suprianingsih ${ }^{1}$, Susa Rita Loravianti ${ }^{2}$, Syafwandi $^{3}$ \\ 1,2 Program Studi Pascasarjana institute Seni Indonesia PadangPanjang \\ ${ }^{3}$ Program Studi Desain Komunikasi Visual, Fakultas Seni Rupa dan Desain, \\ Universitas Negri Padang \\ ${ }^{1}$ Suprianingsih97@gmail.com, ${ }^{2}$ Susasritaloravianti@isi-padangpanjang.ac.id, \\ Syafwandi1960@gmail.com
}

\begin{abstract}
ABSTRAK
Perancangan Game Sebagai Media Pembelajaran Berkebun Hidroponik ialah sebuah perancangan game yang bertujuan sebagai media pembelajaran bagi masyarakat kota medan yang saat ini semakin pesat dengan pengembagan teknologi dan pembangunan yang berdampak pada pengalihan fungsi lahan seperti lahan persawahan dan perkebunan yang saat ini menjadi lahan tinggal dan bangunan industry. Dalam game yang dirancang ini pemain diajak berkebun dengan metode hidroponik yang tidak hanya sekedar bermain saja namun juga belajar karna dalam game ini terdapat informasi bagaimana cara berkebun secara hidroponik mulai dari media-media yang digunakan, cara menyemai, hingga cara perawatan tanaman hidroponik yang akan memberikan pembelajaran pada saat bermain game. Game sering kali dituduh memberikan pengaruh negatif terhadap anak. Faktanya, Game mempunyai fungsi dan manfaat positif bagi anak, di antaranya, anak mengenal teknologi komputer, pelajaran untuk mengikuti pengarahan dan aturan, latihan memecahkan masalah dan logika, melatih saraf motorik dan keterampilan spasial, menjalin komunikasi anak-orangtua saat bermain bersama, serta memberikan hiburan.
\end{abstract}

Kata kunci: Hidroponik, Game, Perancangan

\begin{abstract}
Designing Games as a Hydroponic Gardening Learning Media is a game design that aims as a medium of learning for the city of Medan people who are now increasingly rapid with the development of technology and development that has an impact on the transfer of land functions such as rice fields and plantations that are currently living and industrial buildings. In this designed game players are invited to garden with hydroponic methods that are not just playing but also learning because in this game there is information on how to hydroponic gardening starting from the media used, how to sow, to how to care for hydroponic plants that will provide learning when playing games. Games are often accused of having a negative influence on children. In fact, the game has positive functions and benefits for children, including, children recognize computer technology, lessons to follow directions and rules, practice problem solving and logic, train motor nerves and spatial skills, establish child-parent communication when playing together, and provide entertainment.
\end{abstract}

Keywords: Hydroponics, Games, Designing 


\section{PENDAHULUAN}

Pengalihan fungsi lahan persawahan dan lahan perkebunan konvensional yang mulai digunakan sebagai lahan perumahan, sehingga berkurangnya lahan untuk perkebunan oleh sebab itu perlu dilakukan inovasi dalam berkebun agar masyarakat Kota Medan dapat berkebun dengan lahan yang sempit seperti di halaman rumah, rustops rumah dan perkarangan sekitar rumah yang relatif sempit dengan hasil yang maksimal

Sistem penanaman hidroponik merupakan inovasi perkebunan yang dapat diterapkan pada lahan yang tidak luas dan dapat dilakukan di rustops rumah bertingkat, media yang digunakan dalam sistem berkebun hidroponik ini tidak menggunakan tanah sebagai media tanamnya, namun menggunakan air sebagai media penanamannya. Sifat air yang lebih mudah diaplikasikan di lahan yang sempit, serta bahan-bahan lain yang dibutuhkan untuk berkebun secara hidroponik seperti bak penampungan air, pot tanaman dan yang lainnya dapat memanfaatkan barang-barang bekas yang sudah tidak terpakai lagi seperti, botol air mineral, gelas plastik air mineral, sterofoam bekas buah dan barang-barang bekas lainnya sebgai alat untuk berkebun secara hidroponik.

Bila umumnya berkebun secara konvensional melebar dalam pemanfaatan lahannya, sementara hidroponik menjulang ke atas dalam pemanfaatan lahannya sehingga dengan lahan yang sempit kita dapat menghasilkan tanaman yang cukup berfariasi dan lebih banyak lagi dibandingkan dengan sistem penanaman konvensional. Dengan hidroponik kita juga dapat mengurangi pengeluaran rumah tangga khususnya dalam belanja kebutuhan sayuran sehari-hari yang akan lebih menghemat biaya belanja bulanan.

Pada zaman yang semakin maju oleh pembangunan dan pesatnya perkembangan teknologi informasi yang membuat seluruh lapisan masyarakat Kota Medan dari yang anakanak hingga orang tua tidak dapat lepas dari kebutuhan gadget baik digunakan sebagai media informasi, bisnis, sebagai alat pembelajaran maupun sebagai media hiburan. Gadget memiliki fungsi yang sangat beragam dan semakin berkembang membuat manusia tidak lagi bisa lepas dari benda yang bernama gadget. Beragam aplikasi yang diciptakan untuk menunjang mobilitas para pengguna gadget, seperti aplikasi-aplikasi game pembelajaran yang diciptakan untuk mempermudah dan menarik minat anak-anak untuk belajar sambil bermain yang akan meningkatkan kecerdasan anak.

Gadget ialah perangkat yang memiliki fungsi lebih spesifik, praktis, dan di desain dengan teknologi yang canggih. Seiring dengan perkembangan teknologi dan kebutuhan masyarakat Kota Medan akan kebutuhan teknologi yang dapat dibawa kemana saja dan mudah penggunaannya maka diciptakan Smartphone yang mampu memenuhi kebutuhan mobilitas masyarakat Kota Medan. Saat ini gadget tidak hanya dijadikan sebagai alat komunikasi saja melainkan sebagai alat mencari informasi, bisnis, melakukan transaksi bisnis, maupun sebagai media hiburan.

Perkembangan teknologi informasi memiliki dampak positif dan negatif, Bagitu juga dengan penggunaan gadget. Dampak positif dari penggunaan gadget yaitu mampu mempermudah pekerjaan dan menunjang mobilitas pengguna. Dampak negatif dari penggunaan gadget yaitu membuat berkurangnya interaksi social sang pengguna pada kehidupan sehari-hari. Aplikasi yang tersedia dalam gadget sangat beragam mulai dari aplikasi perbankan, aplikasi bisnis, hiburan, dan aplikasi pembelajaran. Kebiasaan masyarakat Kota Medan yang tidak dapat lepas dari gadget maka dirancang sebuah aplikasi game pembelajaran berkebun hidroponik untuk mengajak masyarakat kota Medan agar mulai mengenal sistem berkebun hidroponik. 
Sistem berkebun hidroponik memiliki peluang yang sangat besar untuk memberikan pembelajaran kepada masyarakat Kota Medan. Penerapan system hidroponik dapat dilakukan di rumah dan dapat membantu memenuhi kebutuhan akan sayur-sayuran dan buah-buahan sehari-hari.

Aplikasi ialah program berbentuk perangkat lunak yang berjalan pada suatu sistem tertentu yang berguna untuk membantu berbagai kegiatan yang dilakukan oleh manusia, yang dirancang untuk memudahkan pekerjaan, menghibur dan mengedukasi masyarakat.

Hidroponik adalah lahan budidaya pertanian tanpa menggunakan media tanah, sehingga hidroponik merupakan aktivitas pertanian yang dijalankan dengan menggunakan air sebagai medium untuk menggantikan tanah. Sehingga sistem bercocok tanam secara hidroponik dapat memanfaatkan lahan yang sempit. Pertanian dengan menggunakan sistem hidroponik memang tidak memerlukan lahan yang luas dalam pelaksanaannya, tetapi dalam bisnis pertanian hidroponik hanya layak dipertimbangkan mengingat dapat dilakukan di pekarangan rumah, rustop rumah maupun lahan lainnya.

Game edukasi berbasis simulasi di desain untuk mensimulasikan permasalahan yang ada sehingga diperoleh esensi atau ilmu yang dapat digunakan untuk menyelesaikan permasalahan tersebut. Game simulasi dengan tujuan edukasi ini dapat digunakan sebagai salah satu media edukasi yang memiliki pola pembelajaran (learning by doing). Berdasarkan pola yang dimiliki oleh game tersebut, pemain dituntut untuk belajar sehingga dapat menyelesaikan permasalahan yang ada. Status game, instruksi, dan tools yang disediakan oleh game akan membimbing pemain secara aktif untuk menggali informasi sehingga dapat memperkaya pengetahuan dan strategi saat bermain.

Di jaman yang serba digital pemanfaatan game sebagai media belajar merupakan hal yang harus mulai digalangkan hal ini di karnakan game merupakan media alternatif yang sangat digemari oleh masyarakat Kota Medan khususnya oleh anak-anak, karna Lewat permainan masyarakat Kota Medan dapat belajar bagaimana cara berkebun secara hidroponik yang baik, dan apa saja manfaat lain dari berkebun hidroponik melalui game.

Untuk mengedukasi dan memperkenalkan metode berkebun hidroponik kepada masyarakat agar lebih mudah diterima maka akan dirancang sebuah game edukasi berkebun hidroponik. Agar masyarakat dapat mengenal hidroponik lewat bermain game edukasi yang diharapkan dapat member pelajaran kepada masyarakat mengenai bagaimana cara berkebun hidroponik. Serta bisa menggugah hati masyarakat untuk mulai menerapkan system berkebun hidroponik di rumah-rumah mereka. Sehingga dapat memperluas lahan hijau di kota-kota besar yang ada diindonesia.

\section{STUDI LITERATUR}

Pada perancangan karya game pembelajaran berkebun hidroponik digunakan metode Glass box yaitu merancang berdasarkan analisis dan sintesis atau disebut dengan metode glass box atau kotak kaca. Metode seperti ini mirip dengan cara kerja komputer, di mana dalam merancang dibutuhkan data, data kemudian diolah atau di-programkan. Hasil pengolahan data ini kemudian menghasilkan out-iput desain. metode baru/rasional (glass box) merupakan metode perancangan rasional disebut sebagai kotak transparant (glass box) merupakan kebalikan dari metode tradisional hasil ciptaan dapat ditelusuri bagaimana proses terjadi maupun proses kreatifnya ciri metode rasional. Tujuan, variable dan kriteria ditentukan dengan matang analisis lengkap evaluasi bermakna dan logis strategi ditentukan dengan matang. 
1. Metode Pengumpulan data

Dalam perancangan game pembelajaran berkebun hidroponik terdapat beberapa metode pengmpulan data yang digunakan ialah metode kualitatif, yaitu metode perancangan yang berbasis riset, data yang dikumpulkan untuk merancang game pembelajaran berkebun hidroponik untuk masyarakat Kota Medan. Data yang dikumpulkan terbagi menjadi dua yaitu data primer dan data sekunder:

a. Data primer

Adapun data primer yang pengkarya peroleh merupakan hasil pengamatan di lapangan yakni sebagai berikut:

1. Belum adanya media pembelajaran berkebun hidroponik yang kreatif, interaktif, dan menarik.

2. Minimnya pengetahuan warga Kota Medan tentang metode berkebun hidroponik.

3. Minimnya kesadaran masyarakat Kota Medan dalam melestarikan lingkungan.

4. Banyaknya lahan berkebun yang beralih fungsi menjadi lahan perumahan.

5. Banyaknya halaman, teras dan rustop rumah yang dibiarkan begitu saja.

b. Data Sekunder

Data yang didapat dari keterangan dan informasi, dari karya-karya tulis yang berkaitan dengan hidroponik, game dan media pembelajaran. Data sekunder ini digunakan untuk memperkuat data-data primer yang telah pengkarya dapatkan, data sekunder ini mudah didapat dan bermanfaat guna perumusan masalah.

\section{Metode Analisa Data}

Dalam mewujudkan sebuah karya game pembelajaran berkebun hidroponik tentunya diperlukan metode analisa atau langkah-langkah dalam riset dan proses kreatiftas, berikut ialah langkah-langkah dalam merancangan game pembelajaran berkebun hidroponik.

1. Persiapan

Dilakukan persiapan berupa studi visual perkebunan hidroponik dengan cara melakukan pengamatan langsung tehadap bagaimana cara berkebun dengan menggunakan metode hidroponik. Pengamatan dilakukan mulai dari pengumpulan data seperti observasi, wawancara, dokumentasi dan studi pustaka. Data yang diperoleh dari kegiatan di atas dijadikan pedoman dalam menggarap karya. Pada proses perancangan game pembelajaran berkebun hidroponik dapat dilihat dengan penjelasan sebagai berikut.

2. Studi Pustaka.

Studi pustaka yang dilakukan dalam merancang game pembelajaran berkebun hidroponik untuk menentukan berbagai sumber yang berkaitan dengan objek penciptaan yakni menelusuri data berupa artikel, video, buku, laporan penciptaan ataupun tulisan yang berkaitan dengan objek, sebagai referensi guna memperluas wawasan yang didapatkan.

3. Teknik Analisa Data

Perancangan game pembelajaran berkebun hidroponik ini menggunakan metode analisa $5 \mathrm{~W}+1 \mathrm{H}$ hal ini penting metode analisa data ini untuk menjawab 
pemecahan masalah dalam proses perancangan game pembelajaran berkebun hidroponik.

\section{W+1H:}

1. What, apa yang akan dibuat? Rancangan yang akan dibuat yaitu perancanga game pembelajaran berkebun hidroponik sebagai sumber ide gagasan.

2. Where, dimana akan diaplikasikan atau diterapkan? Perancangan game pembelajaran berkebun hidroponik nantinya akan diaplikasikan kedalam play store.

3. Who, Siapa target sasaran? Pada perancangan game Pembelajaran Berkebun Hidroponik target sasaran ialah seluruh kalangan masyarakat.

4. When, kapan dimulai? Pada perancangan game Pembelajaran Berkebun Hidroponik dimulai sejak sekarang dan selanjutnya.

5. Why, mengapa diciptakan? Perancangan game Pembelajaran Berkebun Hidroponik diciptakan untuk memberikan pengetahuan bagaimana berkebun hidroponik.

6. How, bagaimana merancang game Pembelajaran berkebun Hidroponik tersebut? Game yang dirancang harus mampu memberikan pembelajaran berkebun hidroponik.

4. Geografis

Geografis aialah ilmu yang mempelajari tentang lokasi serta persamaan, dan perbedaan fenomena fisik manusia di atas permukaan bumi. Pada karya ini geografi yang dituju ialah seluruh kalangan masyarakat lokal maupun manca negara.

5. Demografis

a. Jenis kelamin: Pria dan Wanita

b. Usia: di atas 10 tahun (pelajar, dan semua kalangan).

c. Karakter kepribadian: suka bermain sambil belajar.

d. Why mengapa perancangan gema pembelajaran berkebun hidroponik perlu dibuat? Untuk memberikan pengalam bagaimana berkebun dengan metode hidroponik melalui media game 3D yang berguna untuk memberikan pembelajaran bagaimana berkebun dengan metode hidroponik yang menggunakan air.

e. How bagaimana merancang game pembelajaran berkebun hidroponik? Game yang dirancang haruslah mampu memberikan pengalaman dan pembelajaran tentang cara berkebun dengan metode hidroponik.

\section{Kajian Konsep}

Data-data yang didapatkan selanjutnya diaplikasikan dalam konsep yang akan digarap dalam perancangan game sebagai media pembelajaran berkebun hidroponik. Konsep ini akan digunakan pada tahapan perancangan mulai dari pemilihan jenis tanaman, elemen-elemen yang terdapat pada game serta pola permainan game pembelajaran hidroponik.

4. Visualisasi Perancangan

Setelah malakukan kajian konsep perancangan tahapan selanjutnya ialah visualisasi perancangan. Visualisasi perancangan terdiri dari desain-desain awal setiap 
Suprianingsih, Perancangan Game Sebagai Media... 95

karakter dan elemen-elemen pendukung dalam game pembelajaran berkebun hidroponik. Tahapan ini merupakan akhir dari perancangan yang menghasilkan rancangan final.

\section{PEMBAHASAN}

Kota Medan adalah ibu kota Provinsi Sumatera Utara, Indonesia. Kota ini merupakan kota terbesar di Pulau Sumatera. Kota Medan merupakan pintu gerbang wilayah Indonesia bagian barat dan juga sebagai pintu gerbang bagi para wisatawan untuk menuju objek wisata Brastagi di daerah dataran tinggi Karo, objek wisata Orang hutan di Bukit Lawang, dan Danau Toba.

Medan didirikan oleh Guru Patimpus Sembiring Pelawi pada tahun 1590. John Anderson, orang Eropa yang pertama mengunjungi Deli pada tahun 1833 menemukan sebuah kampung yang bernama Medan. Kampung ini berpenduduk 200 orang dan seorang pemimpin bernama Tuanku. Pada tahun 1886, Medan secara resmi memperoleh status sebagai kota. Tahun 1909, Medan menjadi kota yang penting di luar Jawa, terutama setelah pemerintah kolonial membuka perusahaan perkebunan secara besar-besaran. (id.wikipedia.org/wiki/Kota_Medan\#Sejarah)

Perkembangan Kota Medan yang paling terlihat ialah perubahan fungsi pemanfaatan lahan dari lahan yang bervegetasi menjadi lahan terbangun atau dari lahan pertanian menjadi lahan terbangun baik yang bersifat sebagai tempat bermukim maupun sarana prasarana seperti jalan, pusat industri, dan lain sebagainya. Perubahan ini tentunya sangat berpengaruh terhadap penurun kualitas lingkungan kota yang membutuhkan ruang terbuka hijau sebagai pemasok oksigen dan penyerap karbon yang dihasilkan dari emisi kendaraan dan industri. Perubahan penggunaan lahan juga memiliki andil terhadap terjadinya banjir.

Sebagai kota terbesar ke tiga di Indonesia, kota Medan merupakan kota dengan pertumbuhan dan perkembangan wilayah yang cukup pesat. Hal ini tentunya disebabkan karena cepat pertumbuhan pendudukan di kota Medan yang mengakibatkan kebutuhan lahan semakin tinggi. Perkembangan kota akan berbanding lurus dengan pertumbuhan penduduk, dimana setiap peningkatan pertumbuhan penduduk akan mempengaruhi perkembangan kota (Walbiden, 2010: 8).

\section{Hidroponik}

Hidroponic secara harfiah berarti Hydro = air, dan phonic = pengerjaan. Sehingga secara umum berarti sistem budidaya pertanian tanpa menggunakan tanah tetapi menggunakan air yang berisi larutan nutrient. Budidaya hidroponik biasanya dilaksanakan di dalam rumah kaca (greenhouse) untuk menjaga supaya pertumbuhan tanaman secara optimal dan benar benar terlindung dari pengaruh unsur luar seperti hujan, hama penyakit, iklim dan lain-lain. Keunggulan dari beberapa budidaya dengan menggunakan sistem hidroponik antara lain: Kepadatan tanaman per satuan luas dapat dilipat gandakan sehingga menghemat penggunaan lahan. Mutu produk seperti bentuk, ukuran, rasa, warna, kebersihan dapat dijamin karena kebutuhan nutrient tanaman dipasok secara terkendali di dalam rumah kaca. Tidak tergantung musim/waktu tanam dan panen, sehingga dapat diatur sesuai dengan kebutuhan pasar.

Jenis hidroponik dapat dibedakan dari media yang digunakan untuk berdiri tegaknya tanaman. Media tersebut biasanya bebas dari unsur hara (steril), sementara itu pasokan unsur hara yang dibutuhkan tanaman dialirkan ke dalam media tersebut melalui pipa atau disiramkan secara manual. Media tanam tersebut dapat berupa kerikil, pasir, gabus, arang, zeolite atau tanpa media agregat (hanya air). Yang paling penting dalam menggunakan media tanam tersebut harus 
bersih dari hama sehingga tidak menumbuhkan jamur atau penyakit lainnya (Ida Syamsu Roidah, 2014).

Selain keuntungan diatas ada beberapa keuntungan lain dari system penanaman hidroponik diantaranya ialah:

1.Keberhasilan tanaman untuk tumbuh dan berproduksi lebih terjamin.

2. Perawatan lebih praktis dan gangguan hama lebih terkontrol.

3. Pemakaian pupuk lebih hemat (efisien).

4.Tanaman yang mati lebih mudah diganti dengan tanaman yang baru.

5. Tidak membutuhkan banyak tenaga kasar karena metode kerja lebih hemat dan memiliki standarisasi.

6. Tanaman dapat tumbuh lebih pesat dan dengan keadaan yang tidak kotor dan rusak.

7. Hasil produksi lebih continue dan lebih tinggi disbanding dengan penanama ditanah.

8. Harga jual hidroponik lebih tinggi dari produk non-hydroponic.

9. Beberapa jenis tanaman dapat dibudidayakan di luar musim.

10. Tidak ada resiko kebanjiran, erosi, kekeringan, atau ketergantungan dengan kondisi alam.

11. Tanaman hidroponik dapat dilakukan pada lahan atau ruang yang terbatas, misalnya di atap, dapur atau garasi.

\section{Game Edukasi}

Game sering kali dituduh memberikan pengaruh negatif terhadap anak. Faktanya, Game mempunyai fungsi dan manfaat positif bagi anak, di antaranya, anak mengenal teknologi komputer, pelajaran untuk mengikuti pengarahan dan aturan, latihan memecahkan masalah dan logika, melatih saraf motorik dan keterampilan spasial, menjalin komunikasi anak-orangtua saat bermain bersama, serta memberikan hiburan. Bahkan, bagi pasien tertentu, permainan game dapat digunakan sebagai terapi penyembuhan (Samuel Henry: 2010).

Edukasi adalah proses yang dilakukan oleh seseoarang untuk menemukan jati dirinya, yang dilakukan dengan mengamati dan belajar yang kemudian melahirkan tindakan dan prilaku. Edukasi sebenarnya tidak jauh berbeda dari belajar yang dikembangkan oleh aliran behaviorisme dalam psikologi. Hanya istilah ini sering dimaknai dan diinterpretasikan berbeda dari learning yang bermakna belajar. Dan istilah ini seringkali digunakan dalam pendekatan pendidikan yang tentu maknanya lebih dari sekedar belajar. Secara umum anak usia dini merupakan anak yang berada pada usia 0-6 tahun. Usia dini merupakan usia yang sangat penting bagi perkembangan anak sehingga disebut Golden Age.

Anak usia dini sedang dalam tahap pertumbuhan dan perkembangan yang paling pesat, baik fisik maupun mental. Anak usia dini belajar dengan caranya sendiri. Bila ditinjau dari hakikat anak usia dini, maka anak memiliki dua aspek perkembangan yaitu biologis dan psikologis.

\section{Rancangan Konsep}

Game yang akan dibuat adalah game sederhana bertipe action platformer, dimana pemain akan mengendalikan sebuah karakter yang bergerak di atas sebuah platform (arena). Karakter game yang akan kita buat adalah seorang pemula yang menggunakan baju bermotif ulos batak. Karakter dapat bergerak dengan cara berjalan dan memilih alat dan bahan berkebun hidroponik pada sebuah environment (lingkungan) yang berupa pekarangan rumah adat batak. 
Objective atau tujuan dari game adalah merawat tanaman yang ada dengan cara memberikan nutrisi dan air pada bak penampungan yang ada dan mengumpulkan semua hasil dari tanaman yang telah dirawat. Apabila karakter berhasil mencapai panen dan permainan dinyatakan selesai maka karakter akan dilanjutkan ke tanaman berikutnya. Karakter akan berhenti apabila tanaman yang dirawat menjadi layu dan mati, dan permainan akan dimulai kembali sampai nutrisi habis dan permainan berakhir.

Perancangan tersebut melalui beberapa tahapan design process and planning yaitu:

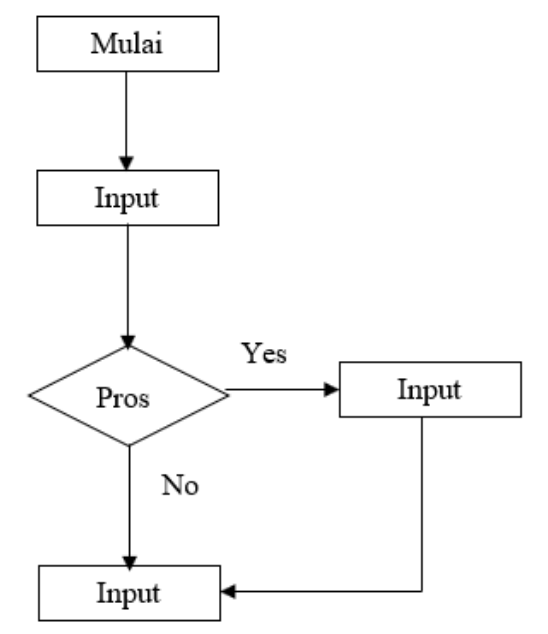

Gambar 1. Flowchart konsep desain game

\section{Proses Penciptaan}

\section{Perencanaan}

Pada tahap perancangan ini yaitu pengumpulan data yang dibutuhkan untuk menganalisa objek material yang dalam hal ini adalah berkebun secara hidroponik dan bahanbahan hidroponik. Data tersebut berupa data visual yaitu foto-foto tumbuhan hidroponik, seperti sayur-sayuran, buah-buahan, dan tumbuhan lainnya. Tahapan perencanaan ini

Kemudian dipetakan ke dalam kebutuhan nutrisi dari setiap tanaman yang memiliki kebutuhan nutrisi yang berbeda-beda.

2. Pembuatan Konsep dari:

Tahapan yang kedua adalah pembuatan konsep desain. Konsep desain disusun mulai

a. Penetapan Desain

Pada perancangan game pembelajaran berkebun hidroponik desain yang akan digunakan untuk back ground, karakter petani, media penanaman dan komponen lainnya akan dirancang menyerupai bentuk asli dari masing-masing karakter.

b. Penetapan Karakter

Penetapan karakter dalam Perancangan game Pembelajaran Berkebun Hidroponik yang akan digunakan nantinya berupa karakter petani, media tanam, 
lahan berkebun, sayur-sayuran, buah-buahan, dan karakter pendukung lainnya.

\section{c. Gerakan/Animasi}

Penetapan garakan atau animasi pada perancangan game Pembelajaran Berkebun Hidroponik akan dirancang sedemikian rupa sehingga setiap gerakan karakter yang ada terlihat nyata dan terlihat lebih hidup.

d. Suara

Penetapan suara dalam perancangan game Pembelajaran Berkebun Hidroponik, suara yang akan digunakan nantinya ialah suara-suara yang dapat menimbulkan efek menyenangkan dan enak didengar, sehingga akan membuat user tidak terganggu denga suara yang dikeluarkan oleh game Pembelajaran Berkebun Hidroponik.

e. Visualisasi karya

Langkah awal dari proses perancangan game pemberlajaran Berkebun Hidroponik tahapan yang dilakukan dari hasil riset ialah rancangan tamplan ke aplikasi digital dengan memakai software Adobe Flesh Professional CS6.

a. Desain Tampilan awal

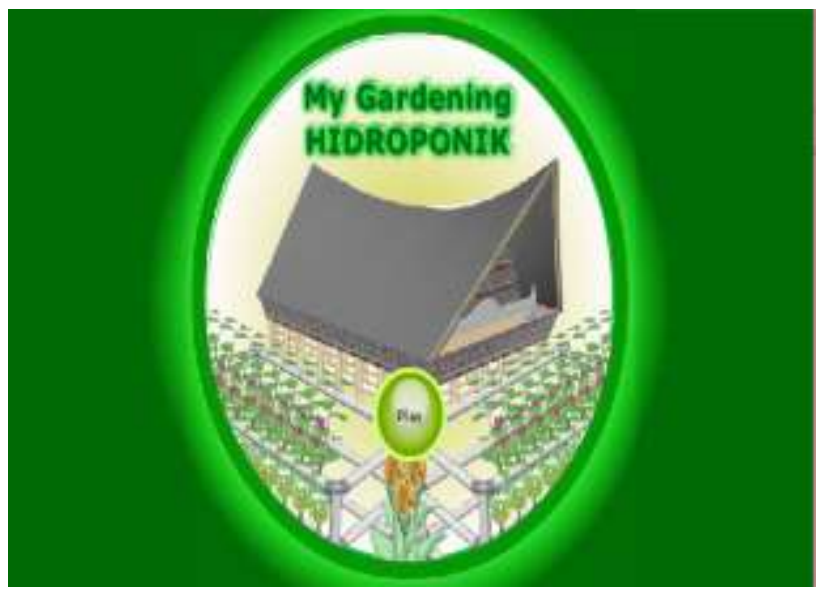

Gambar 2. Tampilan awal game

(Dokumentasi: Suprianingsih, 2018)

Tampilan utama ialah tampilan yang pertama kali dilihat oleh sangpemain dalam gadget atau bisa juga disebuat sebagai icon game. Pada tampilan ini terlihar sebuah rumah adat batak yang menjadi cirikhas dari game pembelajaran Berkebun Hidroponik, tedapat juga dua buah rangkaian pipa paralon yang telah didesai sedemikian rupa sehingga tampak seperti taman hidroponik, terdapat juga tombol play untuk memulai permainan. 
b. Desain Tampilan Menu

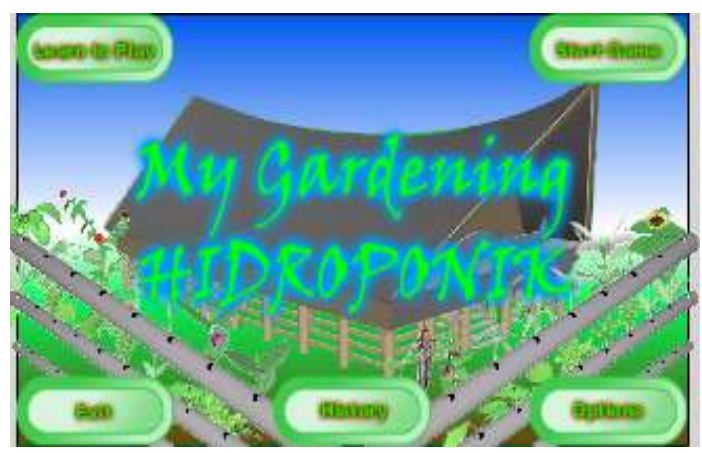

Gambar 3. Tampilan menu game (Dokumentasi: Suprianingsih, 2018)

Tampilan menu merupakan tampilan kedua dari game pembelajaran berkebun hidroponik setelah tampilan icon atau tampilan awal yang pertama kali terlihat pada aplikasi game. Pada tampilan ini pemain akan disuguhkan pada beberapa pilihan yaitu learn to play, start game, exit, history, dan options yang setiap pilihan terdapat berbagai macam informasi mengenai sistem hidroponik.

c. Desain Tampilan Learn to play

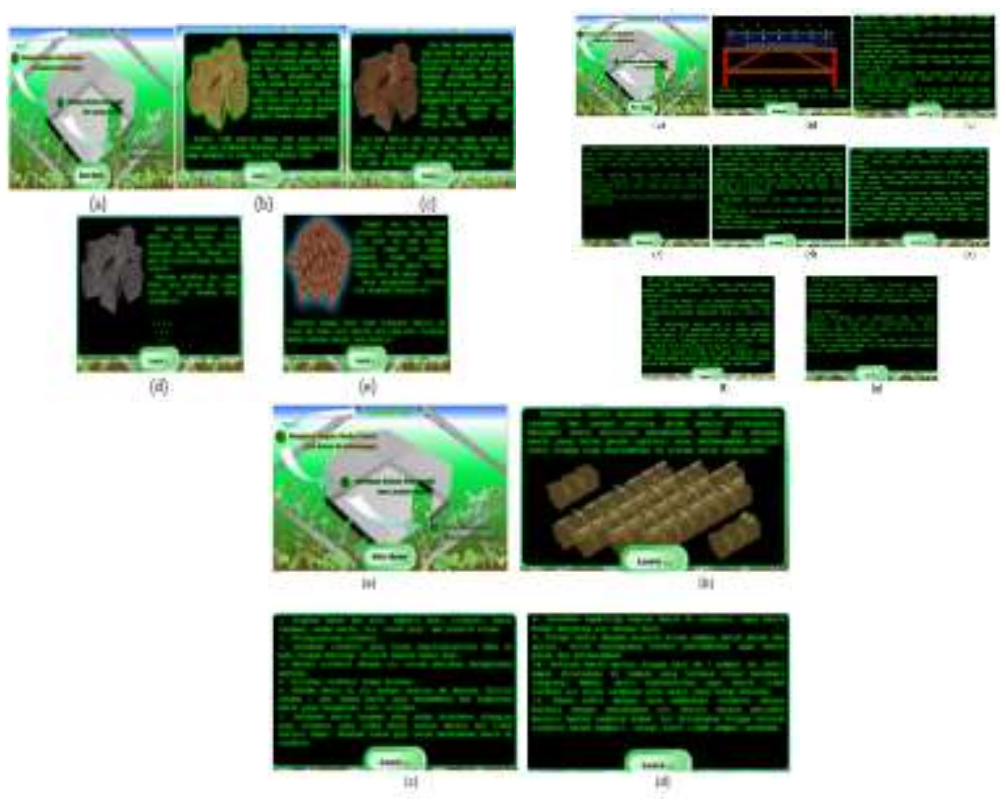

Gambar 4. Tampilan Learn to play

(Dokumentasi: Suprianingsih, 2018)

Learn to play 1 berisikan informasi mengenai ragam media tanam yang terdapat pada system berkebun hidroponik, tidak hanya sekedar menjelaskan mengenaik media tanam saja namun juga memberikan keterangan tentang tanaman apa yang tepat untuk setiap media serta keunggulan dari setiap media tanam yang bisa digunakan dalam system hidroponik. 
Learn to play 2 berisikan sistem-sistem yang terdapat pada metode hidroponik mulain dari sistem rakit apung, sistem sumbuh, sistem NFT (Nutrient Film Technique), dan sistem DFD (Deep Flow Techique) semua sistem ini umum digunakan oleh petani hidroponik. Tidak hanya memperkenalkan sistem yang terdapat pada hidroponik namun juga memberi pengajaran tahapan-tahapan dalam membuat setiap sistemnya.

Learn to play 3 berisikan bagai mana cara menyemai benih untuk sistem hidroponik, mulai dari cara menyiapkan rockwool, melubangi rockwool, pemberian air pada rockwool, menyematkan atau meletakan benih pada rockwool sebagai media tanam. Pada lear to play juga dijelaskan berapa lama waktu yang dibutuhkan untuk benih pecah dan berubah menjadi kecambah, tidak hanya itu dalam learn to play juga dijelaskan bagai mana cara memindahkan benih yang telah menjadi kecambah ketempat pembesaran.

\section{d. Tampilan History}
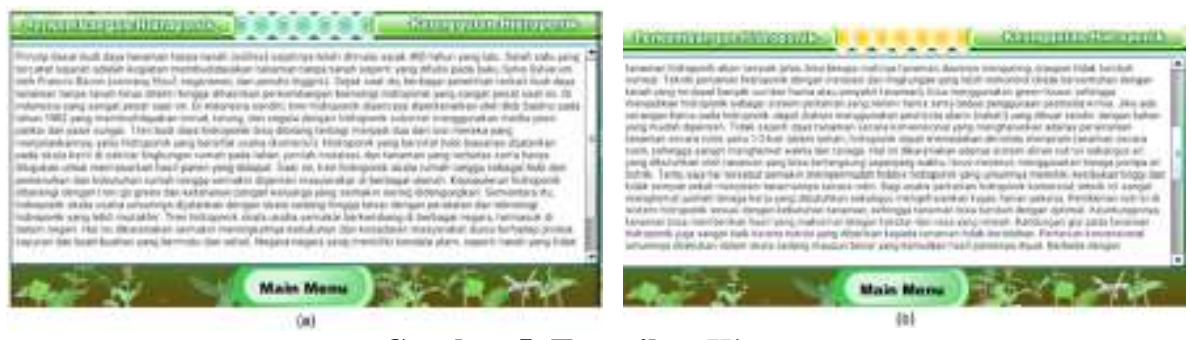

Gambar 5. Tampilan History

(Dokumentasi: Suprianingsih, 2018)

Pada tampilan history ini dijelaskan mengenai sejarah dari sistem penanaman tanpa tanah atau yang lebih dikenal dengan sistem hidroponik, pada history juga dijelaskan mengenai keunggulan dari sistem penanaman hidroponik yang akan semakin menarik minat masyarakat untuk mulai mengaplikasikan sistem hidroponik dirumah mereka.

e. Desain level game
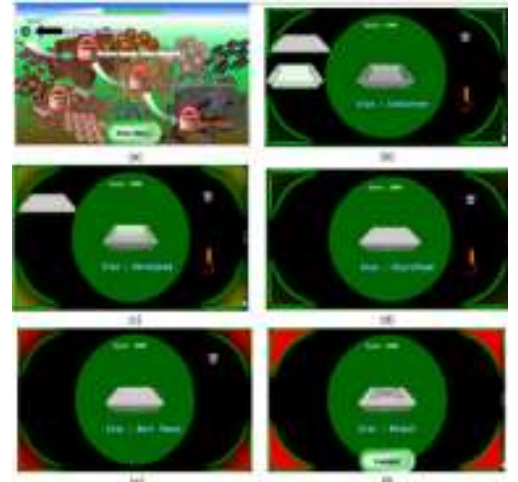

Gambar 6. level 1

(Dokumentasi: Suprianingsih, 2018) 
Pada level 1 tampilan 1 para pemain akan diajarkan bagaimana cara merakit sistem-sistem yang terdapat pada hidroponik yang pertama ialah sistem rakit apung cara bermainya sebagai berikut:

a. Gembok yang terdapat pada sistem rakit apung terbuka makan kita klik angka 1 yang ada pada tampilan.

b. Yang pertama kali harus di tarik ketengah lingkaran yang telah tersedia ialah container yang ada sebelah kanan layar.

c. Lalu tahap selanjutnya yang harus ditarik ketengah lingkaran ialah keranjang yang ada di sebelah kiri layar.

d. Lalu tahap selanjutnya yang harus ditarik ketengah lingkaran ialah steropom yang ada disebelah kiri layar.

e. Lalu tahap selanjutnya yang harus ditarik ketengah lingkaran ialah besih panas yang ada disebelah kanan layar.

f. Lalu tahap selanjutnya yang harus ditarik ketengah lingkaran ialah notpot yang ada disebelah kanan layar.

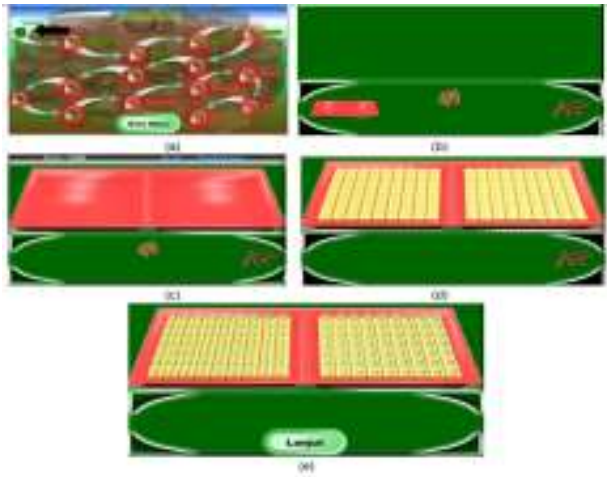

Gambar 7. level 2

(Dokumentasi: Suprianingsih, 2018)

Pada level 2 ini pemain diajarkan bagaimana cara menyemai benih, mulai dari alat-alat yang dibutuhkan, tahapan-tahapan dalam proses penyemaian benih dengan sistem hidroponik. Benih yang pertma kalia ialah semangka, cara bermainya sebagai berikut:

a. Tekan tombol yang betuliskan angka 1 setelah itu akan muncul tamplan berikutnya dilayar.

b. Tarik keatas container yang berwarna merah keatas.

c. Setelah container berada diatas makan yang selanjutnya ditarik keatas ialah meneral stonewool letakan pada container yang telah berada diatas.

d. Makan tahap selanjutnya ialah menarik benih semangkah keatas meneral stonewool setelah selesai.

e. Maka pemain bisa melanjutkan ketahap selanjutnya.

\section{KESIMPULAN}

Game pembelajaran berkebun hidroponik (My Gardening Hidroponik) ialah sebuah media pembelajaran yang berupa game. Yang dirancang menggunakan software Adobe Flash Professional CS6 dan beberapa software pendukung lainnya. 
Game ini dirancang dan dibuat untuk memberikan pembelajaran mengenai cara dan system berkebun secara hidroponik yang diharapkan tidak hanya memberikan pembelajaran bagi para pemain game namun diharapkan juga sebagai media penggugah hati masyarakat kota Medan agar mengetahu system penanaman secara hidroponik dan akan mengaplikasikan system hidroponik dirumah-rumah mereka, terutama masyarakat kota Medan yang memiliki sisah halama depan rumah dan rumah-rumah yang memiliki loteng yang masih banyak digunakan sebagai tempat untuk menjemur pakain dan tempat meletakan tempat penampungan air saja.

\section{V.SARAN}

Karya desain ini merupakan sebuah game mobile yang masih memiliki bayak keterbatasan informasi seputar hidroponik. Sehingga kedepanya bayak dibutuhkan pengembangan lebih lanjut sehingga dapat memberikan informasi sepenuhnya mengenai system penanaman hidroponik.

Diharapkan masyarakat dapat tergugah hatinya untuk mulai mengaplikasikan system hidroponik ini dirumah-rumah mereka, sehingga penghijauan yang diharapkan dapat segera terwujut.

\section{DAFTAR PUSTAKA}

[1] Maulana, Irman. (2014). Pemrograman Game Dengan Actionscript 3.0 Pada Adobe Flash CS6. Yokyakarta: Andi

[2] Wibawanto, Wanda. (2013). Membuat Game Flash 3D Itu Mudah. Yokyakarta: Andi

[3] Wahana Komputer. (2012). Adobe Plash CS6. Yokyakarta: Andi

[4] Wahana komputer. (2014). Mudah Membuat Game Android Berbasis Adobe Air. Yokyakarta: Andi

[5] Arsyad, Azhar. (2013). Media Pembelajaran. Jakarta: Rajawali

[6] Umar, Fadilah Umi, dkk (2018). Jago Bertanam Hidroponik Untuk Pemula. Jakarta: Agro Media Pustaka

[7] Sarwono, Jonthan dan Hary. (2007). Metode Riset Untuk Desain Komunikasi Visual. Yokyakarta: Andi

[8] Asror, Lutfi, dkk (2012). Perancangan Dan Pembuatan Game Online "Penyelamatan Tawanan Perang" Berbasis Html 5 Untuk Penerapan Aplikasi Game Facebook Menggunakan Engine Construct 2: Vol. 13, No. 3 September 2012.

[9] Suptandar, Pamudja. 1995. Manusia Dan Ruang Dalam Proyeksi Interior. Jakarta: UPT Penerbit Universitas Tarumanegara.

[10] Edwardi, Fariki. 2017, 3D Puzzel Rumah Gadang Rajo Babanding: Program Pascsarjana Institit Seni Indonesia. 
[11] Kusmiati, R. Artini. Dkk 1999. Teori Dasar Desain Komunikasi Visual. Jakarta: Djambatan.

[12] Syariefa Evy, Dkk.2014, Hidroponik Praktis, Jakarta: PT. Trubus Swadaya

\section{WEBSTOGRAFI}

https://mindaschool.blogspot.com

http://adinesworld.blogspot.com

http://www.yourgardeninginfo.com

https://www.slideshare.ne

https://mediatani.co/budidaya-hidroponik-strawberr.com

https://id.wikipedia.org/wiki/Kota_Medan\#Sejarah 
